\title{
Beneficial effects of a calf starter versus forage on rumen development and bacteria populations in beef calves
}

\author{
Cándido Enrique Guerra Medina ${ }^{1,2}\left(\mathbb{1}\right.$ Pablo López Gómez ${ }^{1(}$ José de Jesús Maldonado Méndez ${ }^{1}$ \\ Oziel Dante Montañez Valdez ${ }^{2 *}$ José Andrés Reyes Gutiérrez ${ }^{2}$ Alejandro Ley De Coss ${ }^{3}$ (D)
}

\author{
${ }^{1}$ Instituto Nacional de Investigaciones Forestales, Agrícolas y Pecuarias (INIFAP), Campus Rosario Izapa, Tuxtla Chico, Chiapas, México. \\ ${ }^{2}$ Grupo de Investigación en Nutrición Animal (GINA), Centro Universitario del Sur, Universidad de Guadalajara, 49000, Ciudad Guzmán, \\ Jalisco, México. E-mail: montanez77@hotmail.com. "Corresponding autor. \\ ${ }^{3}$ Cuerpo Académico en Desarrollo Agropecuario Sustentable, Facultad de Ciencias Agronómicas, Villaflores, Chiapas, México.
}

\begin{abstract}
Rumen development depends on the intake of solid food that is fermented into volatile fatty acids that stimulate the development of the rumen papillae in calves. The starter feeding can promote the growth of papillae in the rumen and as a consequence an earlier weaning. We evaluated the effects of calf starter on ruminal development, and productive response of lactating bull calves raised for meat in the tropics. Twelve male Brahman $\times$ Swiss American cross beef calves from a dual-purpose system were randomly assigned two treatments with six animals per treatment: milk-fed calves + Taiwan grass (Pennisetum purpureum, MT) and MT + calf starter, (MTS). Feed intake and growth were measured at 7-day intervals throughout until $210 \mathrm{~d}$ of age. At 90 days old, three calves from each treatment were harvested, and fluid and ruminal tissues were collected from the cranial, ventral, dorsal, and dorsal blind ruminal sacs for measurements of many papillaes per $\mathrm{cm}^{2}$ $(N P)$, papillae length $(L P)$ and papillae width (WP). Ruminal bacterial genotype identification was determined by amplicon generation with the Illumina platform. Calf starter-improved weight (Live weight, $L W$ ) and average weight gain (ADG) and NP, but, LP and WP was similar in both treatments $(p<0.05)$. In calves with starter feed treatment, we observed the bacteria Desulfonauticus autotrophicus sp. nov.that was not previously reported in ruminants. Use of calf starter showed benefit for calves with improved feed intake and rumen development because promoted a greater number of rumen papillae.
\end{abstract}

Key words: beef cattle, starter feed,rumen bacteria.

Efeitos benéficos de um concentrado de bezerro versus forragem no desenvolvimento ruminal e na população de bactérias em bezerros

RESUMO: O desenvolvimento dorumen depende da ingestão de alimentos sólidos fermentados em ácidos graxos voláteis que estimulam o desenvolvimento das papilas de rúmen em bezerros. A alimentação inicial pode promover o crescimento das papilas no rúmen e, como consequencia, um desmame mais cedo. Avaliamos os efeitos da concentrado de bezerros no desenvolvimento ruminal, e a resposta produtiva dos bezerros lactantes criados para carne nos trópicos. Doze bezerros de carne bovina cruza Brahman $\times$ suiço-americano machos de de um sistema de dupla finalidade foram aleatoriamente atribuidos adois tratamentos, com seis animais por tratamento: bezerros alimentados com leite + grama taiwanesa (Pennisetumpurpureum, MT) e MT+ concentrado de bezerro, (MTS). A ingestão de ração e o crescimento foram medidos. Aos 90 dias de idade, três bezerros de cada tratamento foi amostrado, e foram coletados tecidos fluidos dos sacos ruminais cranianos, ventral, dorsal e dorsal cegos para medições do número de papilas por $\mathrm{cm}^{2}$ (NP), comprimento das papilas (LP) e largura da papila (PM). A identificação do genótipo das bactérias ruminais foi determinada pela geração de amplicon com a plataforma de ilumine. Oconcentrado de bezerro melhorou o peso $(L W)$ e o ganho diário médio $(A G D)$ e NP, mas, LP e WP foram semelhantes nos dois tratamentos. Bezerros em MTS uma bactéria não encontrada anteriormente em ruminantes Desulfonauticus autotrophicus sp. nov. foi detectado. O uso de concentrado de bezerro mostrou beneficio para bezerros com melhor ingestão de ração e desenvolvimento de rúmen, pois promove um maior número de papilas de rúmen.

Palavras-chave: bovinos de corte, concentrado de bezerro, bactérias do rúmen.

\section{INTRODUCTION}

Dual-purpose livestock represent 78\% of cattle production in the tropical regions of Latin America, and it is estimated that most of the calves destined for beef production come from this system
(SOLORIO et al., 2016). The weaning weights of Brahman and Nellore beef calves, fed without milk restriction, are between 163 at $188 \mathrm{~kg}$ (MEDINA et al., 2005; HERNÁNDEZ et al., 2015); however, the weaning weight of beef calves from a dualpurpose system are lower due to milk restriction 
(SEGURA et al., 2017). This approach limits rumen development and functionality; at weaning, calves have fully undeveloped the capacity to use nutrients from forage, which affects post-weaning weight gain (SIMEONE \& BERETTA, 2016).Rumen epithelium development is affected by the early intake of calf starter because it is fermented in the rumen, producing volatile fatty acids such as propionate and butyrate (KHAN et al., 2016); the latter functions locally in the ruminal wall to stimulate its development (KLEVENHUSEN et al., 2013; XIE et al., 2014). Calves that consume sodium butyrate through the calf starter or milk substitute have longer and wider ruminal papillae, and the weight of the reticulorumen tissue increases (SLUSARCZYK et al., 2010; KATO et al., 2011; WILSON et al., 2012). In addition, sodium butyrate regulates the proliferation, differentiation, and functionality of ruminal epithelial cells (SERBESTER et al., 2014). The calf starter must provide the elements required for the establishment and activity of ruminal microbial species to maximize the production of propionate and butyrate, and favor the development of the ruminal epithelium (DRACKLEY, 2008); facilitating an earlier weaning age, without affecting the productive response postweaning. High-starch diets affect microbial colonization and ruminal development (KHAN et al., 2008; PLAINZIER et al., 2012); therefore, it is important to include ingredients that boost microbial establishment and activity (ABUBACKR et al., 2014). This allows an adequate transition from a liquid to a solid forage-based diet, which in turn allows early weaning without any negative effects on daily weight gain (RASBY, 2007). The establishment of bacterial species in lactating beef calves in the tropics has been scarcely studied. Traditional techniques for cultivating microorganisms, including isolation, characterization, and cell count, have provided information; however, information on the diversity and identification of rumen bacteria are still limited, but molecular techniques have been shown to be more efficient for bacteria species identification (JAMI et al., 2013; JESUS et al., 2015). This study evaluated the effect of calf starter intake on, ruminal development, productive responses and overall bacterial diversity of dual purpose calves in the tropics.

\section{MATERIALS AND METHODS}

\section{Animal, diets, and experimental design}

This experiment was conducted in a cattle production facility dedicated to the study of the dual- purpose system (DPS), located in the Tapachula municipality, in Soconusco, Chiapas, Mexico, between $14^{\circ} 91^{\prime} 36^{\prime \prime}$ north latitude and $92^{\circ} 32^{\prime} 55^{\prime \prime}$ west longitude with an altitude of $177 \mathrm{~m}$. Precipitation from November to April oscillates between 75 and $800 \mathrm{~mm}$, and from May to October period, fluctuating between 1,200 and $3,000 \mathrm{~mm}$. The temperature fluctuates between $18{ }^{\circ} \mathrm{C}$ and $34.5{ }^{\circ} \mathrm{C}$. Chemical analyses of experimental samples were conducted in the Nutrition Laboratory of the University Center of the South of University of Guadalajara, located in Ciudad Guzman, Jalisco, Mexico.

Twelve male Brahman $\times$ Swiss American cross bull calves from a dual-purpose system were randomly assigned two treatments, with six animals per treatment: milk-fed calves + Taiwan grass (Pennisetum purpureum, MT) and MT + calf starter, (MTS). The calf starter was devised according to the nutritional requirements of beef cattle (NRC, 1996). The proportion of ingredients per $100 \mathrm{~g}$, as offered, was as follows: soybean meal $27 \mathrm{~g}$; ground corn 48.60 $\mathrm{g}$; palm kernel meal $22 \mathrm{~g}$ (by-product derived from palm coconut oil extraction of Elaeis guineensis); mineral premix $2 \mathrm{~g}$ (per $100 \mathrm{~g}$ containing: sodium $9.60 \mathrm{~g}$, chlorine $14.40 \mathrm{~g}$, calcium $21.14 \mathrm{~g}$, sulfur 5.20 $\mathrm{g}$, magnesium $0.80 \mathrm{~g}$, zinc $0.42 \mathrm{~g}$, manganese 0.26 $\mathrm{g}$, cobalt $10 \mathrm{mg}$, iodine $4.64 \mathrm{mg}$, and selenium 0.40 $\mathrm{mg}$ ); yeast culture $0.30 \mathrm{~g}$ (Saccharomyces cerevisiae, live culture yeast cells: 2 x $10^{9} \mathrm{CFU} \mathrm{g}^{-1}$ ); and microminerals $0.10 \mathrm{~g}$ (selenium methionine $590 \mathrm{ppm}$, zinc di-lysine 3,000 ppm, iodine peptide $30 \mathrm{ppm}$, cobalt peptide $30 \mathrm{ppm}$, chromium methionine 990 ppm, copper di-lysine 500 ppm, manganese di-lysine 3,000 ppm, iron di-lysine 1,500 ppm, and vitamin $\mathrm{E}$ $50 \mathrm{IU} \mathrm{kg}^{-1}$ ). Taiwan grass was harvested every day, freshly chopped, and offered to the calves at $0700 \mathrm{~h}$ and $1300 \mathrm{~h}$. All animals had unlimited access to clean water and chopped Taiwan grassand werehoused in individual pens, additionally, the calves in the MTS treatment had free access to the calf starter at 08:00 and 13:00 h.

\section{Chemical analysis}

The experimental feed sare shown in Table 1. Samples were dried in a circulating air oven at $60{ }^{\circ} \mathrm{C}$ for $24 \mathrm{~h}$ and then milled in a hammer mill equipped with a $2 \mathrm{~mm}$ sieve for further analysis. Total dry matter (DM) was determined using a circulating air oven. Crude protein (CP) was determined by the Kjeldahl method, and ethereal extract (EE) and ash content, after incineration of the samples in a muffle at $550{ }^{\circ} \mathrm{C}$, were calculated from the difference using the technique described by AOAC (2007). 
The determination of the fiber fractions, neutral detergent fiber (NDF) and acid detergent fiber (ADF), was performed using alpha amylase without ash correction, as specified by VAN SOEST et al. (1991).

\section{Handling and feeding}

The calves suckled the mother's colostrum in the first three hours of life, the navel was disinfected with 3\% iodine solution, and the calf weight was recorded with a digital scale with $300 \mathrm{~kg}$ capacity and $0.1 \mathrm{~kg}$ accuracy no later than $24 \mathrm{~h}$ after birth. The calves remained with the mother constantly during the first 20 days, and, from day seven, the milking of the residual milk began. From day 21 onward, after the morning milking (08:00 h), all calves were allowed to nurse the dam for $30 \mathrm{~min}$ and were subsequently separated from the mother until the next day. The calves were weaned at seven months of age $(210 \mathrm{~d})$ in the MT treatment and at 90 days of age in the MTS treatment to determine possible differences in rumen development by the effect of the calf starter. At $90 \mathrm{~d}$ of age, was orally administered an endoparasiticide, a single dose of $2 \mathrm{~mL}$ per $45 \mathrm{~kg}$ of live weight (each $100 \mathrm{~mL}$ contained $13.0 \mathrm{-g}$ albendazole and $1.0 \mathrm{~g}$ of cobalt sulfate). Five milliliters of vitamins were administered intramuscularly (each $\mathrm{mL}$ contained 500,000 IU of vitamin A palmitate, 75,000 IU of vitamin D3 cholecalciferol, 50 IU of vitamin E tocopherol, and 1,560 $\mu \mathrm{g}$ of phosphorus).

\section{Growth performance and calf starter feed intake}

Calves were weighed at birth at 7-day intervals until $210 \mathrm{~d}$ of age, weight was recorded and the average weight gain (ADG) was calculated weekly. Consumption of calf starter was measured daily throughout the experiment to estimate the intake and the remaining feed was weighed at each delivery time $24 \mathrm{~h}$ later.

\section{Ruminal papillae development}

Three calves were harvested from each treatment at 90 days of age, according to the Norma Oficial Mexicana promulgated in the Official Journal of the Federation (NOM-044-ZOO-1995). The digestive system, from the esophagus to the large intestine, was removed. A portion from the rumen and to the beginning of the small intestine was dissected, the contents of the compartments were emptied, washed with water until clean and free of digestive content, and samples of ruminal tissue were collected. To complete 20 observations per rumen cavity per treatment, each sac of the rumen (cranial, ventral, dorsal and dorsal blind) was dissected into sections of approximately $16 \mathrm{~cm}^{2}$; four sections of each sac were taken at random and, from each of them, five samples of approximately $1 \mathrm{~cm}^{2}$ were removed to evaluate the number of papillae per $\mathrm{cm}^{2}$ (NP), length (LP), and papillae width (WP).

\section{Number of ruminal papillae per $\mathrm{cm}^{2}$}

Each sample was placed on a slide and observed under a microscope with a $4 x$ lens and a graduated ocular with an observation field of 9 $\mathrm{mm}^{2}$ and precision of $0.025 \mathrm{~mm}$. In the center of each $1 \mathrm{~cm}^{2}$ sample, we counted the total papilla in an observation area of $9 \mathrm{~mm}^{2}$, and we calculated the number of papillae per $\mathrm{cm}^{2}$ from the data obtained.

\section{The length and width of the papillae}

From each $1 \mathrm{~cm}^{2}$ sample, a papillae in the center of the observation field was randomly chosen, and the length of the papilla from the base to the apex and the width at the base was measured.

\section{Identification and molecular characterization of ruminal bacteria}

After calves euthanized, $50 \mathrm{~mL}$ of ruminal liquid from the cranial, ventral, dorsal, and dorsal blind sacs were taken from rumen digesta samples and were filtered three times through sterile gauze; $30 \mathrm{~mL}$ were then deposited in sterile vials and immediately stored at $-196{ }^{\circ} \mathrm{C}$ in liquid nitrogen for rumen $16 \mathrm{~S}$ rRNAanalysis.DNA was extracted from $50 \mu \mathrm{L}$ of ruminal fluid using the ZymoBIOMICS ${ }^{\mathrm{TM}}$ DNA Miniprep kit (Zymo Research Corp., Irvine, CA, USA), according to the manufacturer's instructions, and the DNA concentration was determined by spectrophotometry (STULNIG \& AMBERGER, 1994). The identification of ruminal bacteria genotype, were determined by the use of amplicon generation with the Illumina platform using the forward primer 5' TCG GCA GCG TCA GAT GTG TAT AAG AGA CAG CTC CTA CGG GAG GCA G 3' and the reverse primer 5' GTC TCG TGG GCT CGG AGA TGT GTA TAA GAG ACA GCT TGT GCG GGC CCC CGT CAA TTC 3.'

After amplification, the fragments were purified using Ampure XP and a gene library was created according to sequencing by synthesis (SBS) platform, with the Illumina MiSeq system (Illumina, Analysis Software version: 2.6.2.3), in the $2 \times 300$ run format, which has the capacity to generate approximately $12 \mathrm{~Gb}$ and guarantee 20,000 readings per sample, with the use of amplicons. Once the libraries were generated, quantification, preparation 
of the equimolar pool of the libraries, sequencing run, data separation for analysis and bioinformatics analysis were conducted.

\section{Statistical analysis}

The data obtained from the productive and papillae development variables were subjected to using PROC GLM of SAS (Statistical Analysis System, version 9.0). Significance was set at $\mathrm{P}<0.05$. The statistical model used was

$Y_{i j}=\mu+T_{i}+\delta_{j}+\varepsilon_{i j}$ where $Y_{i j}$ is the response variable; $\mu$ is the general mean; $T_{i}$ fixed effect of $i^{\text {th }}$ traetment (MT or MTS); $\delta_{i j}$ ramdom effect of calf; $\varepsilon_{i j}$ is the error associated with measurement taken from calf $j$ from $i^{\text {th }}$ treatment.

\section{RESULTS}

The calf starter intake $(\mathrm{kg})$ increased from month two when the feed was offered as free access; it increased from month 2-4 as the percentage of LW, but decreased in month 5 (Table 2). In month 2, calf starter intake was $0.42 \mathrm{~kg}$ calf ${ }^{-1} \mathrm{~d}^{-1}$ and represented $0.58 \%$ of the LW; at the time of weaning ( 3 months of age), it was $0.99 \mathrm{~kg}$ calf ${ }^{-1} \mathrm{~d}^{-1}$ and represented $1.22 \%$ of the LW. In the postweaning period, it increased to $1.56 \mathrm{~kg}$ calf ${ }^{-1} \mathrm{~d}^{-1}$ in month 4 and represented $1.64 \%$ of the LW. The birth and live weights from ages 1 to 5 months were similar between treatments ( $\mathrm{P}=$ formal style please fix all others $>0.05)$, but in months 6 and 7, LW was higher $(\mathrm{P}<$ 0.05 ) in calves receiving the MTS treatment (Table 3 ). The ADG was similar between treatments in months 1 to 4 (P> $0.05)$ and was higher in MTS calves at 5 to 7 months. The average from birth to 210 days of age $(\mathrm{P}<0.05$; Table 4$)$ was also higher in MTS. In this study, the starter feed intake improved the ADG in the post-weaning period.
The number of ruminal papillaes per $\mathrm{cm}^{2}$ was higher in the cranial, ventral, dorsal, and caudodorsal sacs of calves fed with calf starter $(\mathrm{P}<0.05)$, this was possibly due to the stimulation of ruminal papillae proliferation in various sacs (Table 5). The ruminal papillae length (LP) was higher in the rumen ventral sac of calves fed with calf starter $(\mathrm{P}<0.05)$, but there was no difference between treatments in the cranial, dorsal, and caudo-dorsal sacs (Table 6). There was no difference in the papillae width in the ventral and dorsal rumen sacs $(\mathrm{P}>0.05)$, but it was higher $(\mathrm{P}<0.05)$ in the cranial sac of calves fed with the MT and in the caudo-dorsal sac of the calves fed with the MTS treatment (Table 7).

The molecular identification of the ruminal bacteria, according to bioinformatics analysis, resulted in 28 different phyla; At level phylum, Bacteroidetes was the most abundant bacteria, (average relative abundance of $41 \%$ ) followed by Firmicutes (33 $\%)$, Proteobateria (5.5\%), Actinobacteria (1.38\%), Verrucomicrobia $(0.80 \%)$ and Nitrospire $(0.65 \%)$. Fibrobacteres $(0.81 \%)$ were identified in the MT group and the Tenericutes $(0.57 \%)$ in calves with MTS (Figure 1). At the genus level, 474 genera were detected. Eight genera were predominant, but their relative abundances were different. Provotella was the most abundant genus in all treatments; however, the Butyrivibrio genus was only present in the MT group and for the calves with starter feed, we observed the bacteria Desulfonauticus autotrophicus had been not previously reported in ruminants (Table 8, Figure 1).

\section{DISCUSSION}

In this study, the starter feed intake was $0.99 \mathrm{~kg}$ at the time of weaning (3 months of age),

Table 1 - Chemical composition of the calf starter and the Taiwan grass.

\begin{tabular}{lcc}
\hline Chemical composition & Calf starter & Taiwan grass \\
\hline Dry matter & $---1 .-1.0$ & 91.80 \\
Crude protein & 93.32 & 7.18 \\
Ethereal extract & 17.46 & 2.72 \\
Crude fiber & 3.38 & 32.61 \\
Neutral detergent fiber & 12.52 & 55.34 \\
Acid detergent fiber & $\mathrm{ND}^{1}$ & 31.37 \\
Ash & $\mathrm{ND}$ & 13.44 \\
\hline
\end{tabular}

${ }^{1} \mathrm{ND}$ : not determined. 
Table 2 - Calf starter intake by beef calves from a dual-purpose system, base as offered.

\begin{tabular}{|c|c|c|}
\hline Month of age & $\mathrm{Kg}_{\text {calf }}{ }^{-1} \mathrm{~d}^{-1}$ & $\%$ of live weight \\
\hline 2 & 0.42 & 0.58 \\
\hline 3 & 0.99 & 1.22 \\
\hline 4 & 1.56 & 1.64 \\
\hline 5 & 1.92 & 1.55 \\
\hline 6 & 2.00 & 1.38 \\
\hline 7 & 2.10 & 1.20 \\
\hline
\end{tabular}

and it increased to $1.56 \mathrm{~kg}$ at month 4 and $1.92 \mathrm{~kg}$ at month 5 , corresponding to 1.22 and $1.55 \%$ of LW at 3 and 5 months, respectively. According to the National Research Council (NRC, 1996), a beef calf between 10 and 22 weeks of age should consume 2.50 to $3.00 \%$ of their LW. SWEENEY et al. (2010) suggested that, to achieve an adequate transition without affecting the post weaning ADG, the calf starter intake must be maintained at $1.20 \mathrm{~kg} \mathrm{~d}^{-1}$ due to the correlation that exists between both variables (HAISAN et al., 2019).

The calf starter intake observed in this study was lower than that reported by CASTRO \& ELIZONDO (2012), who fed Holstein calves with calf starter as meal and the intake was $1 \mathrm{~kg} \mathrm{~d}^{-1}$ at 2 months of age and $1.42 \mathrm{~kg} \mathrm{~d}^{-1}$ during the transition at 42 to 55 days of age. During the transition, from lactating to weaning, the consumption of milk affects the calf starter intake (SAEGUSA et al., 2017). HAISAN et al. (2019) observed that, in Holstein calves, the intake was $1.07 \mathrm{~kg} \mathrm{~d}^{-1}$ when the milk intake was $5 \mathrm{~L} \mathrm{~d}^{-1}$ and decreased to $0.72 \mathrm{~kg} \mathrm{~d}^{-1}$ when it was $10 \mathrm{~L} \mathrm{~d}^{-1}$. In calves from dual-purpose systems with milk restriction, this could have positive effects during the transition. As observed in this study, the quantity of feed intake was enough to produce a larger number of papillae in the different ruminal sacs of calves fed with MTS treatment, which facilitated weaning at three months of age without any effect on the ADG and a positive effect on LW and ADG in the post-weaning period.

The live weight of calves in the months 1 to 5 was similar between both groups; whereas, in months 6 and 7, it was higher in the calves fed

Table 3 - Live weight of beef calves from the dual-purpose system, from birth to seven months of age (210 d).

\begin{tabular}{|c|c|c|c|}
\hline Month of age & MT & MTS & $\mathrm{SEM}^{2}$ \\
\hline \multicolumn{4}{|c|}{------------------------------------------Kg------------------------------------- } \\
\hline Birth & 34.2 & 35.4 & 3.6 \\
\hline 1 & 56.0 & 57.9 & 7.6 \\
\hline 2 & 69.9 & 71.9 & 11.9 \\
\hline 3 & 83.1 & 81.0 & 13.8 \\
\hline 4 & 95.4 & 95.2 & 16.5 \\
\hline 5 & 102.9 & 123.7 & 17.5 \\
\hline 6 & $109.4^{\mathrm{b}}$ & $145.2^{\mathrm{a}}$ & 17.7 \\
\hline 7 & $122.7^{\mathrm{b}}$ & $175.0^{\mathrm{a}}$ & 16.2 \\
\hline $\begin{array}{l}\text { Change of the live weight } \\
\text { from birth to } 210 \text { days }\end{array}$ & $88.4^{\mathrm{b}}$ & $139.5^{\mathrm{a}}$ & 17.7 \\
\hline
\end{tabular}

a,b Different letters in the same row indicate statistical difference between treatments $(\mathrm{P}<0.05)$; ${ }^{1} \mathrm{MT}$ : milk fed calves + Taiwan grass; MTS: MT + calf starter. ${ }^{2}$ SEM: standard error of the media.

Ciência Rural, v.51, n.5, 2021. 
Table 4 - Average daily gain $\left(g\right.$ calf $\left.{ }^{1} \mathrm{~d}^{-1}\right)$ of beef calves from the dual-purpose system, from birth to seven months of age $(210 \mathrm{~d})$.

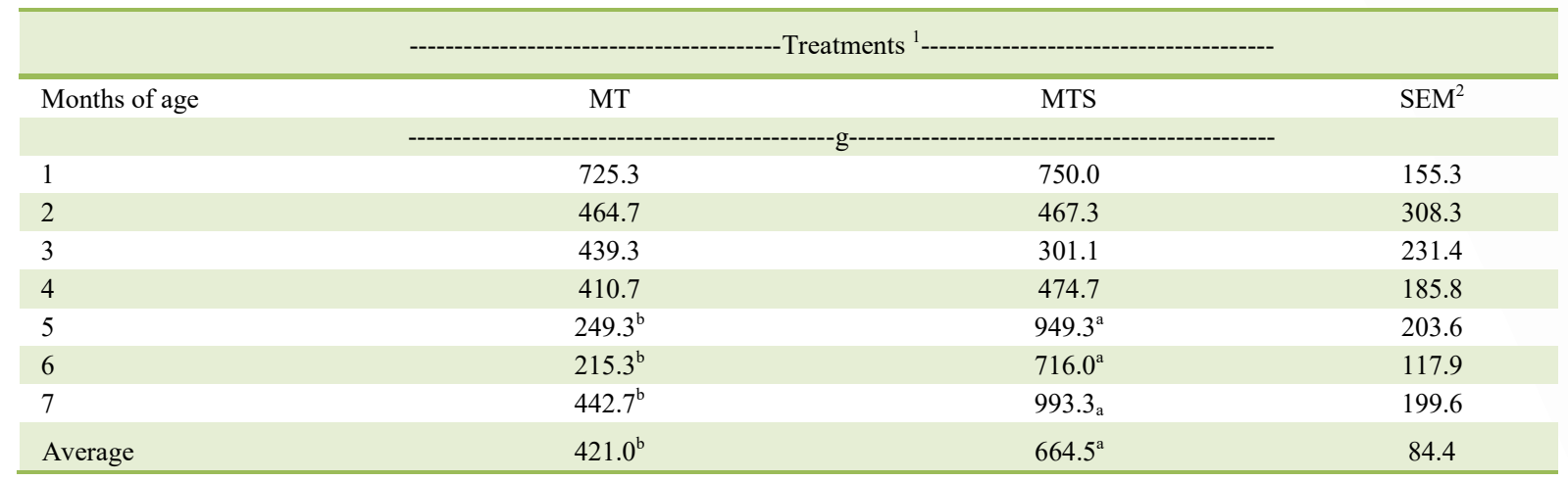

${ }^{\mathrm{a}, \mathrm{b}}$ Different letters in the same row indicate statistical difference between treatments $(\mathrm{P}<0.05)$; ${ }^{1} \mathrm{MT}$ : milk fed calves + Taiwan grass; MTS: MT + calf starter. ${ }^{2}$ SEM: standard error of the media.

with MTS. At seven months of age, the calves in the MT treatment weighed $122.7 \mathrm{~kg}$ while calves in the MTS treatment weighed $175.0 \mathrm{~kg}$; these results suggested that the $52.3 \mathrm{~kg}$ difference was due to the calf starter intake since they were weaned at three months of age. The live weight of the calves in the MTS treatment was higher than the weight at weaning, adjusted to 210 days $(168.8 \mathrm{~kg})$, of Nelore calves reported by MEDINA et al. (2005), and lower than that reported by HERNÁNDEZ et al.(2015), who recorded Brahman calves $188.0 \mathrm{~kg}$ at 205 days in (both without milk restriction). When we compare the LW of the DPS beef calves at 7 months of age obtained in this study with the weight of the beef calves reported by MEDINA et al. (2005) and
HERNÁNDEZ et al. (2015), the difference is $46.1 \mathrm{~kg}$ and $65.3 \mathrm{~kg}$, respectively. In another study, SEGURA et al.(2017) reported that weight at weaning in beef calves is associated with breed, maternal ability, milk available to the calf, and handling, where the intake of calf starter is determinant because affects the weaning weight. Therefore, results of this study suggested that calves fed starter feed after 21 days of age and weaned at three months have a weaning weight similar to that of beef calves without milk restriction.

SANDOVAL et al. (2005) showed that milk consumption affects the ADG of DPS calves in the first 3 months of age, and as lactation progresses, the effect of milk decreases due to the lower milk consumption. This was observed in MT fed calves,

Table 5 - Number of papillae per $\mathrm{cm}^{2}$ in the cranial, ventral, dorsal, and caudodorsal sacs in the rumen of calves from a dual-purpose system at three months of age $(90 \mathrm{~d})$.

\begin{tabular}{|c|c|c|c|}
\hline Rumen cavity & MT & MTS & $\mathrm{SEM}^{2}$ \\
\hline \multicolumn{4}{|c|}{ 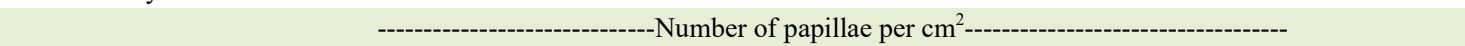 } \\
\hline Cranial sac & $110^{\mathrm{b}}$ & $259^{\mathrm{a}}$ & 24.06 \\
\hline Ventral sac & $150^{\mathrm{b}}$ & $299^{\mathrm{a}}$ & 47.57 \\
\hline Dorsal sac & $140^{\mathrm{b}}$ & $262^{\mathrm{a}}$ & 35.29 \\
\hline Caudodorsal sac & $162^{\mathrm{b}}$ & $235^{\mathrm{a}}$ & 27.73 \\
\hline
\end{tabular}

${ }^{\mathrm{a}, \mathrm{b}}$ Different letters in the same row indicate statistical difference between treatments $(\mathrm{P}<0.05)$; ${ }^{1} \mathrm{MT}$ : milk fed calves + Taiwan grass; MTS: MT + calf starter. ${ }^{2}$ SEM: standard error of the media. 
Table 6 - Papillae length $(\mathrm{mm})$ in the cranial, ventral, dorsal, and caudodorsal ruminal sacs of calves from a dual-purpose system at three months of age (90).

\begin{tabular}{|c|c|c|c|}
\hline Rumen cavity & MT & MTS & $\mathrm{SEM}^{2}$ \\
\hline \multicolumn{4}{|c|}{ 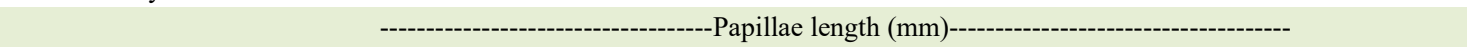 } \\
\hline Cranial sac & 1.97 & 2.02 & 0.30 \\
\hline Ventral sac & $0.68^{\mathrm{b}}$ & $1.13^{\mathrm{a}}$ & 0.14 \\
\hline Dorsal sac & 0.67 & 0.63 & 0.12 \\
\hline Caudodorsal sac & 0.39 & 0.32 & 0.06 \\
\hline
\end{tabular}

${ }^{\mathrm{a}, \mathrm{b}}$ Different letters in the same row indicate statistical difference between treatments $(\mathrm{P}<0.05)$; ${ }^{1} \mathrm{MT}$ : milk fed calves + Taiwan grass; MTS: MT + calf starter. ${ }^{2}$ SEM: standard error of the media.

where ADG decreased after 4 months of age; whereas, in MTS fed calves, they observed a positive response due to the increase in calf starter intake showing an ADG of $949 \mathrm{~g}$ calf $^{-1} \mathrm{~d}^{-1}$ in month 5 and $993 \mathrm{~g}$ calf ${ }^{1} \mathrm{~d}^{-1}$ at 7 months. Similarly, BETANCOURT et al. (2012) reported that in lactating calves supplemented with calf starter plus a yeast culture (Saccharomyces cerevisiae), ADG was $732 \mathrm{~g} \mathrm{calf}^{-1} \mathrm{~d}^{-1}$. CASTILLO et al. (2018) reported an ADG of $450 \mathrm{~g} \mathrm{calf}^{-1} \mathrm{~d}^{-1}$ in the first month of age and $1077 \mathrm{~g} \mathrm{calf}^{-1} \mathrm{~d}^{-1}$ in the third month of age, when the calf starter intake was 2.9 $\mathrm{kg}$ calf $^{-1} \mathrm{~d}^{-1}$ in calves weaned at 4 months of age. Calves fed with calf starter had a higher number of papillae per $\mathrm{cm}^{2}$ in the ventral, cranial, dorsal, and caudo-dorsal ruminal sacs; it has been suggested that lactating calves fed with fermentable carbohydraterich diet, the production of butyrate is higher, which promotes the development of the ruminal epithelium
(KHAN et al., 2008; SIMEONE \& BERETTA 2016). This may be due to the increase in the metabolism of butyric acid in the ruminal epithelial cells (GÓRKA et al., 2009; PENNER et al., 2011), which oxidizes to $\beta$-hydroxybutyrate and is later absorbed, increasing its plasmatic concentration (LESMEISTER \& HEINRICHS, 2004).

CASTRO and ELIZONDO (2012) reported an average papillae length of $1.93 \mathrm{~mm}$ and width of $0.98 \mathrm{~mm}$ from different rumen cavities of eight-weekold Holstein calves that consumed $1.0 \mathrm{~kg} \mathrm{~d}^{-1}$ of calf starter as meal. SHIN et al. (2011) observed a higher papillae length $(2.24 \mathrm{~mm}$ vs $2.54 \mathrm{~mm})$ in 42-dayold Holstein calves that received sodium butyrate in the milk replacer with a starter intake of $0.4 \mathrm{~kg}$ calf $^{-1} \mathrm{~d}^{-1}$. Thus, it is important to stimulate calfstarter intake at an early age in beef calves and to include ingredients that promote the development of ruminal

Table 7 - Papillae width $(\mathrm{mm})$ in the cranial, ventral, dorsal, and caudodorsal ruminal sacs of calves from a dual-purpose system at three months of age $(90 \mathrm{~d})$.

\begin{tabular}{|c|c|c|c|}
\hline & ------ & -------- & \\
\hline \multirow[t]{2}{*}{ Rumen cavity } & MT & MTS & $\mathrm{SEM}^{2}$ \\
\hline & -------. & ------ & \\
\hline Cranial sac & $0.71^{\mathrm{a}}$ & $0.58^{\mathrm{b}}$ & 0.06 \\
\hline Ventral sac & 0.48 & 0.59 & 0.08 \\
\hline Dorsal sac & 0.68 & 0.61 & 0.07 \\
\hline Caudodorsal sac & $0.46^{\mathrm{b}}$ & $0.64^{\mathrm{a}}$ & 0.03 \\
\hline
\end{tabular}

${ }^{\text {a, b }}$ Different letters in the same row indicate statistical difference between treatments $(\mathrm{P}<0.05)$; ${ }^{1} \mathrm{MT}$ : milk fed calves + Taiwan grass; MTS: MT + calf starter. ${ }^{2}$ SEM: standard error of the media. 


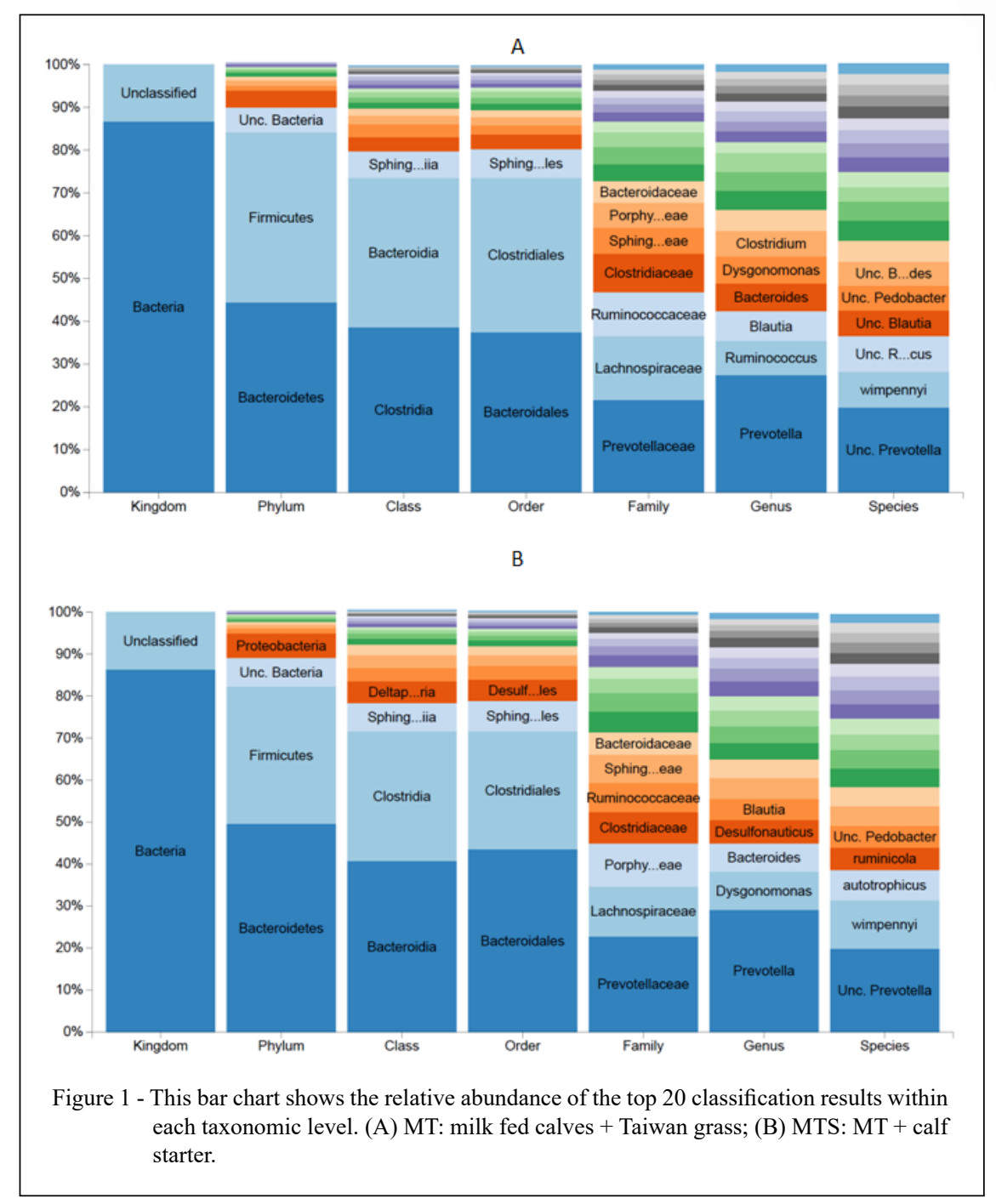

microorganisms. In this study, the calf starter led to a positive response in the development of ruminal papillae and ADG, probably by the inclusion of palm kernel meal in the formulation.

In pre-ruminants, is difficult to study the impact of host age alone due the con-founding effect of the diet because undergo from a whole milk based to a solid based diet in a short time for the early rumen development (MALMUTHUGE \& GUAN, 2017; O'CALLAGHAN et al., 2018), but, Bacteroidetes, Fimicutes and Proteobacteriahave been reported as the most dominant phyla in the rumen (WU et al. 2012). In our study, the most predominant bacteria in the MT calves ruminal fluid were Prevotella (15\%), Ruminococcus (4\%), and Blautia (4\%), whereas, in MTS, they were Prevotella (16\%), Dysgonomonas
(5\%), and Bacteroides (4\%); however, from day 15 to 83 of age, the populations dramatically changed in response to starter feeding: Prevotella increased to $42 \%$ and the other genera decreased to less than $0.1 \%$. LI et al. (2012) observed in calves fed with a milk-replacer, an increase, from the $2^{\text {th }}$ to the $6^{\text {th }}$ week of the relative abundance of Bacteroidetes, a decrease in Firmicutes and Proteobacteria. However, REY et al. (2014) evaluated the bacterial populations established in the rumen of dairy calves, from days 5 to 12 , and reported that the predominant genera were Bacteroides (21\%), Prevotella (11\%), Isobacterium (5\%), and Streptococcus (4\%), those results are different to ours.

We reported the presence of the bacteria Desulfonauticusautotrophicus sp. nov. (3 \%) in 
Table 8 - Top genus classification results at the bacterial ruminal diversity of beef calves from a dual-purpose system at three months of age $(90 \mathrm{~d}, \%)$.

\begin{tabular}{|c|c|c|}
\hline & 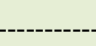 & ------ \\
\hline Classification & MT & MTS \\
\hline Unclassified at genus level & 28.16 & 29.07 \\
\hline Prevotella & 15.03 & 16.03 \\
\hline Bacteroides & 3.61 & 3.76 \\
\hline Blautia & 3.85 & 2.84 \\
\hline Ruminococcus & 4.28 & 2.38 \\
\hline Dysgonomonas & 3.38 & 4.92 \\
\hline Clostridium & 3.50 & 2.87 \\
\hline Butyrivibrio & 2.62 & absent \\
\hline Desulfonauticus autotrophicussp. nov. $\neq$ & absent & 3.09 \\
\hline
\end{tabular}

${ }^{1}$ MT: milk fed calves + Taiwan grass, weaned at seven months of age; MTS: MT + starter feed, weaned at 90 days of age. Total Genuslevel Taxonomic Categories Identified: 456.

the rumen of calves fed MTS a species that has not previously been reported in ruminants. This bacteria was isolated from production water of an oil field in Northern Germany near Hamburg and described by MAYILARAJ et al. (2009) as a novel, moderately thermophilic and halophilic, sulfate-reducing bacterium. The cells were Gram-negative, straight to slightly curved rods, and motile by a single polar flagellum; they grew well between 40 and $62{ }^{\circ} \mathrm{C}$, but the optimum conditions for growth were $58^{\circ} \mathrm{C}$ and a pH 7.8. Both temperature and $\mathrm{pH}$ differ with what was reported in this study, where the ruminal temperature was approximately $38^{\circ} \mathrm{C}$ and pH 6.18, but, Desulfonauticus autotrophicus, a strictly anaerobic bacterium, which is consistent with the rumen conditions, and could be related to the inclusion of palm kernel meal in the calf starter; however, the ecological role of this bacteria in the rumen microbial ecosystem, needs to be further investigated.

ABUBACKR et al. (2014), using palm kernel cake to feed goats, observed an increase in the population of total and cellulolytic bacteria, such as Ruminococcus albus and Ruminococcus flavefaciens, while, the population of methanogenic and protozoan bacteria decreased; CHANJULA et al. (2010) reported that by including more than $35 \%$ of palm meal in the diet, the concentration of volatile fatty acids decreased in the rumen.

\section{CONCLUSION}

The consumption of calf starter by calves of the dual-purpose system in the tropics, for 21 days of age, promoted a greater number of rumen papillae. Weaning at 90 days of age does not affect the live weight or average dairy gain, but in the post-weaning period, the response to the calf starter by the variables mentioned is higher. The presence of species Desulfonauticus autotrophicus sp. nov has not been previously reported in ruminants, and we considered that its presence may be due to the inclusion of palm kernel meal; however, further research is required for the isolation, identification, and description of the bacteria activity of ruminants fed with this ingredient.

\section{ACKNOWLEDGMENTS}

The results are part of the fiscal project 2018 SIGI: 13212634416, "Production of high quality and safe beef in the tropics of Mexico.

\section{DECLARATION OF CONFLICTS OF INTERESTS}

The authors declare no conflict of interest. The founding sponsors had no role in the design of the study; in the collection, analysis, or interpretation of data; in the writing of the manuscript, and in the decision to publish the results.

\section{AUTHORS' CONTRIBUTIONS}

All authors contributed equally for the conception and writing of the manuscript. All authors critically revised the manuscript and approved of the final version. 


\section{REFERENCES}

ABUBACKR, A. A. R. et al. Effect of feeding palm oil byproducts based diets on total bacteria, cellulolytic bacteria and methanogenicarchea in the rumen of goats. Plos One, v.9, n.9, p.e95713, 2014. Available from: <https://dx.doi. org/10.1371\%2Fjournal.pone.0095713>. Accessed: Jun. 10, 2020. doi: 10.1371/journal.pone.0095713.

AOAC. Official methods of analysis of AOAC International. 18thed. Gaithersburg, MD, USA. 2007.xzk

BETANCOURT, L. et al. Manejo nutricional de terneros cebú comercial sometidos a amamantamiento restringido y destete precoz en el Pidemonte de Casanare. Revista Colombiana de Ciencia Animal, v.5, p.21-30, 2012. Available from: <https://docplayer. es/46189189-Manejo-nutricional-de-terneros-cebu-comercialsometidos-a-amamantamiento-restringido-y-destete-precoz-en-elpiedemonte-de-casanare.html>. Accessed: Jun 10, 2020.

CASTILLO, O. J. O. et al. Respuesta productiva de becerros lactantes suplementados con alimento iniciador más cultivo de levaduras (Saccharomyces cerevisiae). Acta Universitaria, v.28, n.1, p.9-14, 2018. Available from: <http://www.scielo.org.mx/scielo. php?script=sci_arttext\&pid=S0188-2662018000100009\&lng=es\&n rm=iso >. Accessed: Jun. 10, 2020. doi: 10.15174/au.2018.1709.

CASTRO, F. P.; ELIZONDO, S. J. A. Crecimiento y desarrollo ruminal en terneros alimentados con iniciador sometido a diferentes procesos. Agronomía Mesoamericana, v.23, n.2, p.343-352, 2012. Available from: <http://www.scielo.sa.cr/scielo. php?script=sci_arttext\&pid=S1659-13212012000200013\&lng=en $\& n r m=i s o>$. Accessed: Jun. 10, 2020.

CHANJULA, P.; MESANG, A. et al. Effects of dietary inclusion of palm kernel cake on nutrient utilization, rumen fermentation characteristics and microbial populations of goats fed Paspalum plicatulum hay-based diet. Songklanakarin Journal of Science and Technology, v.32, n.6, p.527-536, 2010. Available from: <https:// rdo.psu.ac.th/sjstweb/journal/32-6/0125-3395-32-6-527-536.pdf> . Accessed: Jun. 10, 2020

DRACKLEY, J. K. Calf nutrition from birth to breeding. Veterinary Clinics of North American: Food Animal Practice, v.24, n.1, p.55-86, 2008. Available from: <https://www.sciencedirect.com/ science/article/abs/pii/S0749072008000029>. Accessed: Jun 10, 2020. doi:10.1016/j.cvfa.2008.01.001.

GÓRKA, P.Z.M. et al. Effect of sodium butyrate supplementation in milk replacer and starter diet on rumen development in calves. Journal of Physiology and Pharmacology, v.60, n.3, p.47-53, 2009. Available from: $<$ http://www.jpp.krakow.pl/journal/archive/10 09 s3/pdf/47_10_09_s3_article.pdf $\$$. Accessed: Jun. 10, 2020.

HAISAN, J. M. A.; STEELE, D. J. A. et al.Effects of amount of milk fed and starter intake. On performance of group-housed dairy heifers during the waning transition. Applied Animal Science, v.35, n.1, p.88-93, 2019. Available from: $<$ https://www. sciencedirect.com/science/article/abs/pii/S2590286519300059>. Accessed: Jun. 10, 2020. doi:10.15232/aas.2018-01812.

HERNÁNDEZ, H.N. et al. Non-genetic effects on growth characteristics of Brahman cattle. Revista MVZ Córdoba, v.20. n.1, p.427-435, 2015. Available from: $<\mathrm{https}: / /$ revistas unicordoba. edu.co/index.php/revistamvz/article/view/72>. Accessed: Jun. 10, 2020. doi: $10.21897 / \mathrm{rmvz} .72$
JAMI, E. et al. Exploring the bovine rumen bacterial community from birth to adulthood. The ISME Journal Multidisciplinary Journal of Microbial Ecology, v.7, p.1069-1079, 2013. Available from: <https://www.nature.com/articles/ismej20132>. Accessed: Jun. 10, 2020. doi: 10.1038/ismej.2013.2.

JESUS, R. B. D. Bacterial diversity in bovine rumen by metagenomic 16S rDNA sequencing and scanning electron microscopy. Acta Scientiarum Animal Sciences, v.37, n.3, p.251257, 2015. Available from: <http://citeseerx.ist.psu.edu/viewdoc/ download?doi=10.1.1.864.4587\&rep=rep1\& type $=$ pdf $>$. Accessed: Jun. 10, 2020. doi: 10.4025/actascianimsci.v37i3.26535.

KATO, S. I. et al. Effects of Na-butyrate supplementation in milk formula on plasma concentrations of $\mathrm{GH}$ and insulin, and on rumen papilla development in calves. Journal of Endocrinology, v.211, n.3, p.241-248, 2011. Available from: <https://pdfs. semanticscholar.org/0b0c/591b806c883ba5453ff88650707adae4 9e45.pdf $>$. Accessed: Jun. 10, 2020. doi: 10.1530/joe-11-0299.

KHAN, M.A. et al. Starch source evaluation in calf starter, II Ruminal parameters, rumen development, nutrient digestibilities, and nitrogen utilization in Holstein calves. Journal of Dairy Science, v. 91, n. 3, p.1140-1149, 2008. Available from: <https:// www.sciencedirect.com/science/article/pii/S0022030208713705>. Accessed: Jun. 10, 2020. doi:10.3168/jds.2007-0337.

KHAN, M.A. et al. Invited review: Transitioning from milk to solid feed in dairy heifers. Journal of Dairy Science, v.99, n.2 p.885-902, 2016. Available from: <https://www.sciencedirect. com/science/article/pii/S0022030215009236>. Accessed: Jun. 10, 2020. doi: $10.3168 /$ jds.2015-9975.

KLEVENHUSEN, F. et al. Feeding barley grain-rich diets altered electrophysiological properties and permeability of the ruminal wall in a goat model. Journal of Dairy Science, v.96, n.4,p.2293-2302, 2013.Available from: <https://www.sciencedirect.com/science/ article/pii/S0022030213000970>. Accessed: Jun. 10, 2020. doi: $10.3168 / j$ ds.2012-6187.

LESMEISTER, K. E.; HEINRICHS, A. J. Effects of corn processing on growth characteristics, rumen development, and rumen parameters in neonatal dairy calves. Journal of Dairy Science, v.87, p.n. 10, 3439-3450, 2004. Available from: <https://www.sciencedirect.com/ science/article/pii/ S0022030204734797>. Accessed: Jun. 10, 2020. doi: 10.3168/jds.S0022-0302(04)73479-7.

LI, R.W. et al. Characterization of the rumen microbiota of pre-ruminan calves using metagenomic tools. Environmental Microbiology, v.14, n.1,p.129-139.2012. Available from: $<$ https://sfamjournals.onlinelibrary. wiley.com/doi/pdf/10.1111/j.1462-2920.2011.02543.x?casa token=J0MYT8JOrhYAAAAA:Irx6As dFsGVBaqd1bEk hBT5wlIDqpErCAonOtQItlcGxaia1pgJz8TjnyOlpcrKFqYrbA>. Accessed: Aug. 22, 2020. doi: 0.1111/j.1462-2920.2011.02543.

MALMUTHUGE, N.; GUAN, L.L. Understating host-microbial interactions in rumen: searching the best opportunity for microbiota manipulation. Journal of Animal Science and Biotechnology, v.8, n.8, p.8, 2017. Available from: <https://link.springer.com article/10.1186/s40104-016-0135-3>. Accessed: Aug. 22, 2020. doi: 10.1186/s40104-016-0135-3.

MAYILARAJ, S. et al. Desulfonauticus autotrophicus sp. nov., a nove thermophilic sulfate-reducing bacterium isolated from oil-production water and emended description of the genus Desulfonauticus. Extremophiles, v.13, n.2, p.247-255, 2009. Available from: <https:// 
link.springer.com/article/10.1007/s00792-008-0212-4>. Accessed: Jun. 10, 2020. doi: 10.1007/s00792-008-0212-4

MEDINA, Z. J. M.; OSORIO, A.M. et al. Influencias ambientales y parámetros genéticos para características de crecimiento en ganado Nelore en México. Revista Científica FCV-LUZ, v.15, n.3, p.235-241, 2005. Available from: <https://www.redalyc.org/ pdf/959/95915307.pdf>. Accessed: Jun 10, 2020.

NRC. Nutrient Requirements of Beef Cattle. 8thed. The National Academies Press. Washington, D. C. 1996.

O'CALLAGHAN, F.T. et al. Pasture changes the bovine rumen and milk metobolome. Metabolites, v. 8, n. 2, p.1-24, 2018. Available from: < https://www.mdpi.com/2218-1989/8/2/27/htm>. Accessed: Aug. 22, 2020. doi: 10.3390/metabo8020027.

PENNER, G.B. et al. Ruminant Nutrition Symposium: Molecular adaptation of ruminal epithelia to highly fermentable diets. Journal of Animal Science, v.89, n.4, p.1108-1119, 2011. Available from: $<$ https://pdfs.semanticscholar.org/8f86/33d3f4b704ec37ced6bec d291b3f64b23942.pdf>. Accessed: Jun. 10, 2020. doi: 10.2527/ jas.2010-3378.

PLAINZIER, J. C. et al. Subacute ruminal acidosis (SARA), endotoxins and health consequences. Animal Feed Science and Technology, v.172, n.1-2, p.9-21, 2012. Available from: <https:// www.sciencedirect.com/science/article/pii/S0377840111004937> Accessed: Jun. 10, 2020. doi: 0.1016/j.anifeedsci.2011.12.004

RASBY, R. 2007. Early weaning beef calves. Veterinary Clinics of North America: Food Animal Practice, v.23, p.29-40, 2007. Available from: $<$ http://www.fazendaparaiso.net/assets/weaning-beefcows.pdf $>$. Accessed: Jun. 10, 2020. doi: 10.1016/j.cvfa.2007.01.002.

REY M. et al. Establishment of ruminal bacterial community in dairy calves from birth to weaning is sequential. Journal of Applied Microbiology, v.116. n.2, p.245-257, 2014. Available from: $<$ https:// sfamjournals.onlinelibrary.wiley.com/doi/pdf/10.1111/jam.12405>. Accessed: Jun 10, 2020. doi: 10.1111/jam.12405.

SAEGUSA, A. K. et al. Effect of partial replacement of corn grain with lactose in calf starters on ruminal fermentation and growth performance. Journal of Dairy Science,v. 100, n. 8, p. 6177-6186, 2017. Available from: <https://www.sciencedirect.com/science/ article/pii/S0022030217305969>. Accessed: Jun. 10, 2020. doi: $10.3168 /$ jds.2017-12616.

SANDOVAL, E.A. et al. Evaluación de pesos al nacer y crecimiento en becerros de doble propósito amamantados con vacas nodrizas durante la etapa de lactantes. Zootecnia Tropical, v.23, n.1, p.116, 2005. Available from: <https://tspace.library.utoronto.ca/ bitstream/1807/9377/1/zt05001.pdf>. Accessed: Jun. 10, 2020.

SEGURA, C.J.C. et al. Breed and environmental effects on birth weight, weaning weight and calving interval of cebu cattle in southeastern México. Tropical and Subtropical Agroecosystems, v.20, n.2, p.297-305, 2017. Available from: <http://www.revista. ccba.uady.mx/ojs/index.php/TSA/article/view/2338>. Accessed Jun. 10, 2020.

SERBESTER, U. et al. Effect of feeding starter containing butyrate salt on pre- and posweaning performance of early or normally weaned calves. Revue de MedecineVeterinaire, v.165, p. n. -2, 44-48, 2014. Available from: <https://www.revmedvet.com/2014/ RMV165_44_48.pdf $>$. Accessed: Jun. 10, 2020.
SHIN, I. K. et al. Effects of Na-Butyrate supplementation in milk formula on plasma concentration of $\mathrm{GH}$ and insulin, and on rumen papilla development in calves. Journal of Endocrinology, v.211, n.3, p.241-248, 2011. Available from: <https://pdfs. semanticscholar.org/0b0c/591b806c883ba5453ff88650707adae4 9e45.pdf $>$. Accessed: Jun. 10, 2020. doi: 10.1530/JOE-11-0299.

SIMEONE, A.; BERETTA, V. Early weaning: an efficient and effective technological alternative for calf rearing corrals in grassland. Cattle Systems in Latin America. Cuban Journal of Agricultural Science, v.50, n.1, p.39-49, 2016. Available from: <http://cjascience.com/index.php/CJAS/article/view/595>. Accessed: Jun. 10, 2020.

SLUSARCZYK, K. et al. The effect of sodium butyrate on calf growth and serum level of B-hidroxibutyric acid. Journal of Animal and Feed Science, v.19, n.3, p.348-357, 2010 Available from: <https://pdfs.semanticscholar.org/5909/ f90f39d8387246fc33c117418751d236eee5.pdf $>$. Accessed: Jun. 10, 2020. doi: $10.22358 /$ jafs/66298/2010.

SOLORIO, F.J. et al. The potential of silvopastoral systems for milk and meat organic production in the tropics. In: NANDWANI D. Organic Farming for Sustainable Agriculture. Sustainable Development and Biodiversity. Springer International Publishing Switzerland, 2016. p.169-183.

STULNIG, T. M.; AMBERGER A. Exposing contaminating phenol in nucleic acid preparations. Biotechniques,v.16, p. n. 3, 402-404, 1994

SWEENEY, B.C. et al. Duration of weaning, starter intake, and weight gain of dairy calves fed large amounts of milk. Journal of Dairy Science, v.93, n. 1, p.148-152, 2010. Available from: $<$ https:// www.sciencedirect.com/science/article/pii/S0022030210702745>. Accessed: Jun. 10, 2020. doi: 10.3168/jds.2009-2427.

VAN SOEST, P. J. et al. Methods for dietary fiber, neutral detergent fiber and nonstarch polysaccharides in relation to animal nutrition. Symposium: carbohydrate methodology, metabolism, and nutritional implications in dairy cattle. Journal of Dairy Science, v.74, n.10, p.3583-3597, 1991.Available from: <https://www. journalofdairyscience.org/article/S0022-0302(91)78551-2/pdf $>$. Accessed: Jun. 10, 2020. doi: 10.3168/jds.S0022-0302(91)78551-2.

WILSON, D. J.; MUTSVANGWA, T. et al. Supplemental butyrate does not enhance the absorptive or barrier functions of the isolated ovine ruminal epithelia. Journal of Animal Science, v.90, n.9, p.3153-3161, 2012. Available from: $<$ https://pdfs.semanticscholar. org/5c94/d88c205a7a7d4ee2c0711d920b1704cf56a2.pdf $>$. Accessed: Jun 10, 2020. doi: 10.2527/jas.2011-4315.

WU, S. et al. The bacterial community composition of bovine rumen detected using pyrosequencing of 16 rRNA genes. Metagenomics, v.1, n.11, p.1-11. 2012. Available from: $<$ https://pdfs.semanticscholar. org/27d4/ff604fbda06fbe61d05323a6567539e9d95d.pdf? $\mathrm{ga}=2.131335880 .610540758 .1598487585-1080085425.1591994363>$. Accessed: Aug. 26, 2020. doi: 10.4303/mg/235571.

XIE, X. X. et al. Effects of a mixture of steam flaked corn and extrudes soybean on performance, ruminal development, ruminal fermentation, and intestinal absorptive capability in veal calves. Journal of Animal Science, v.91, n.9, p.4315-4321, 2014. Available from: <https://pdfs.semanticscholar.org/f57c/89888bd 6b6eab7a1d32cf1b81354ff0bfa93.pdf>. Accessed: Jun. 10, 2020. doi: $10.2527 /$ jas.2012-5731. 